\title{
For Art's Sake
}

\section{Minnesota's Creative Makerspace}

HEATHER ACERRO

I

n September 2012, we opened an Art Room in Youth Services at Rochester (MN) Public Library. Inspired by an article in Children and Libraries ${ }^{1}$ and heavily influenced by Bridget Matros's chapter in 20UNDER40: Re-Inventing the Arts and Arts Education for the 21st Century, ${ }^{2}$ the Art Room-a converted office space in the public area with a wall of windows-is where children exercise their creativity by exploring art techniques and materials. It is an unrestricted creative space, meaning they can create freely with the supplies on hand.

During the first year, 8,824 kids and grown-ups used the space-an average of 735 people each month.

Our library received a $\$ 1,000$ grant from Rochester Arts Council and \$2,200 in private donations to purchase furniture and supplies, as well as install laminate flooring. The furniture includes two tables, ten stools, two drawer units, a display shelf, and a small book shelf used for book displays outside of the room.
We also purchased and laminated some colorful paper frames and cut out the center to display art that kids left behind. But we were not expecting the huge volume of art that we received, and after a few months, we put out tape dispensers and let the kids put their own art on display. Watching the blank walls slowly get covered with art throughout the month is one of the best parts of the experience of the Art Room.

\section{During the first year,} 8,824 kids and grownups used the space-an average of 735 people each month.
We also purchased a lot of basic art supplies as well as special items necessary for the themes we offered, such as Sequential Art (Comics), Masks, Flags, Lines in Art, 3-D Paper Sculptures, and Collage. For each theme, we changed out the supplies available and created a display poster introducing the technique or concept.

In June 2013, we surveyed users of the Art Room and the results were encouraging. Eighty-two percent of parents who responded said they somewhat to strongly agreed that their children show more interest in creative projects after visiting the Art Room. The same percentage somewhat to

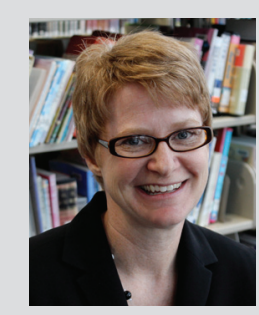

Heather Acerro is the Head of Youth Services at Rochester (MN) Public Library where she is building an innovative, dynamic, and interactive space for children to learn, collaborate, and create. She writes reviews for School Library Journal, serves on the board of The Reading Center: Dyslexia Institute of Minnesota, and is the current chair of the ALSC Intellectual Freedom Committee. 


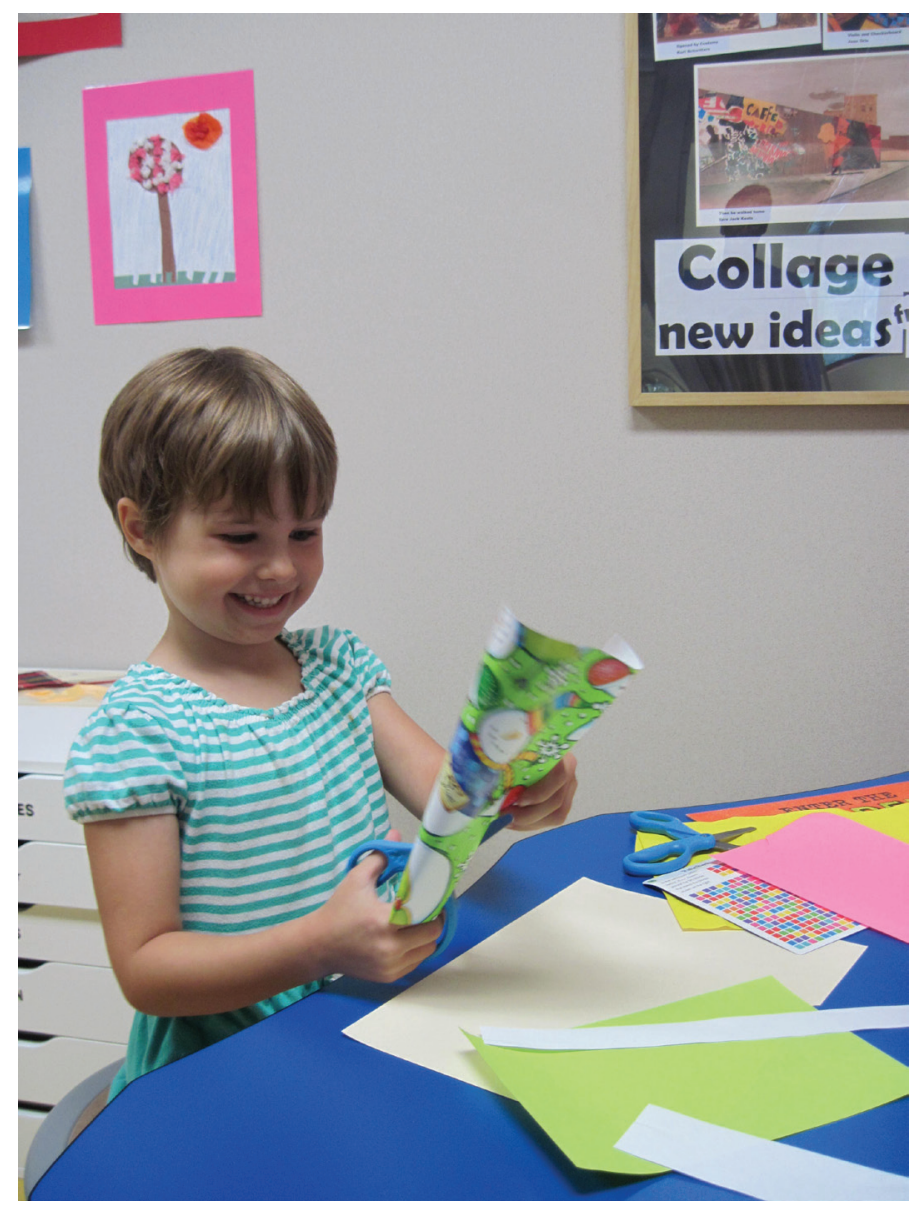

Ada in the Art Room.

strongly agreed that their children create more art because the Art Room is available. Other statistics showed:

- 79 percent of parents surveyed strongly agreed that the Art Room is a valuable activity for their family.

- 75 percent of parents strongly agreed that their children ask to visit the Art Room.

- 69 percent said the Art Room makes them feel happy.

- 67 percent said the Art Room makes them feel creative.

In the first year, we learned a lot about what our visitors enjoyed about the Art Room. To our surprise, the kids didn't really care for the themes and changing art materials, but preferred to have a wide variety of materials and tools always available. So we then discarded the monthly themes and instead featured

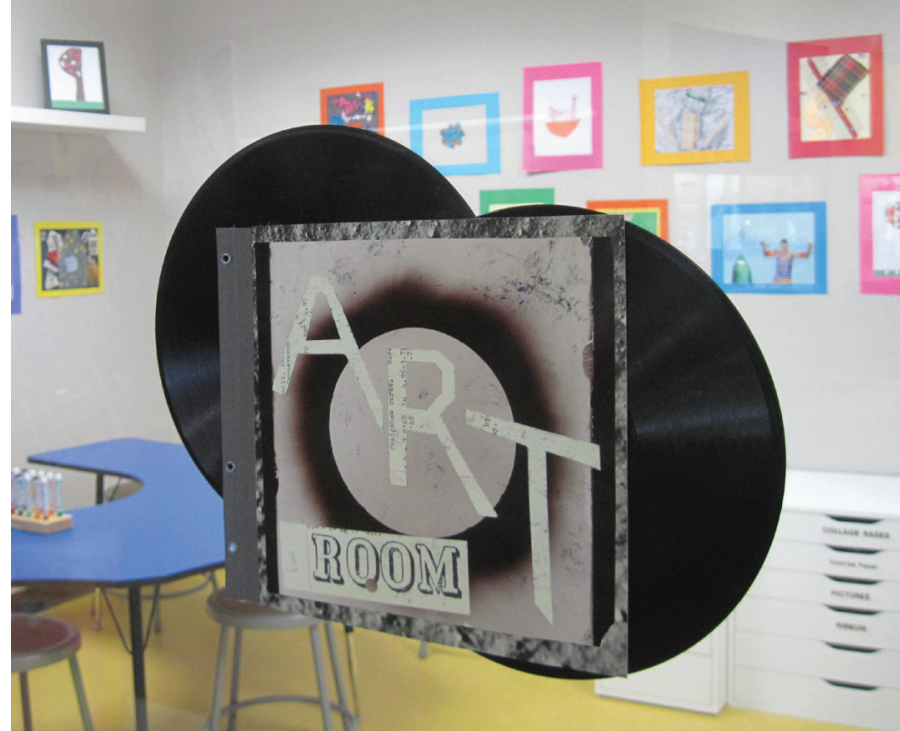

The Art Room sign.

a particular artist, movement, or technique on a poster in the room for inspiration.

Materials are available in labeled drawers and trays, for kids to use however they like. While we do not staff the room, it does require constant maintenance; we clean and restock the room sometimes several times a day. There are times when the room is a disaster after a long and busy day, but we have not had any major behavior or theft issues. Children, for the most part, respect the space and the artwork on display.

The Art Room is a well-loved creative space both in our library and our community. Building on this success, we recently opened a similar teen art space. Staff and customers are continually delighted to see the art left on display and to watch children learn and create. \&.

\section{References}

1. Maria V. Kramer, “Taking Part in Art,” Children and Libraries 8, no. 2 (Summer 2010): 31-37.

2. Bridget Matros, "Handprint Turkeys and the Cotton Ball Snowmen: Is There Hope for an Artful America?" in 20UNDER40: Re-Inventing the Arts and Arts Education for the $21^{s t}$ Century, edited by Edward P. Clapp (Bloomington, IN: Authorhouse, 2010): 310-30. 